TPeriodica Polytechnica Civil Engineering

62(4), pp. 1067-1075, 2018

https://doi.org/10.3311/PPci.11965

Creative Commons Attribution (i)

\section{An Experimental Study on the Strengthening of RC Frames with Soft Storey Irregularities with Different Types of Steel Diagonals}

\author{
Murat Ozturk $^{1 *}$, Tevfik F. Ogutcu ${ }^{1}$ \\ Received 16 January 2018; Revised 16 June 2018; Accepted 04 October 2018
}

\begin{abstract}
When the loss of life and property is considered, it is clear that special precautions must be taken against the earthquakes among the natural disasters. Post-earthquake observations, especially those made in the developing countries, reveal that there are many reasons for the damage and loss of life, not just one. The formation of soft storey irregularity is one of the most important factors among them. In this study, it is aimed to propose an alternative strengthening method to eliminate the adverse effects of the formation of a soft storey irregularity. Four identical frames with two stories and single span were constructed and tested under reverse cyclic loading which simulates the earthquake. The first frame among them was prepared by bonding bricks as an infill wall on two stories and it was considered to be the reference frame. In the 2 nd frame, the formation of soft storey irregularity was facilitated by removing the infill wall on the lower story and the behavioral differences were examined. The remaining two frames were strengthened by using steel elements in two different diagonal shapes on the lower story. As a result, the experimental study showed that the strengthening with steel diagonal elements increased the lateral load-carrying capacity of the frame with soft storey behavior by $250 \%$ and the energy dissipation by $120 \%$ and also provided better results than the reference frame.
\end{abstract}

\section{Keywords}

soft storey, RC frame, damage, strengthening

\footnotetext{
1 Department of Civil Engineering

Faculty of Engineering,

SelcukUniversity

Konya,Turkey

*Corresponding author, email: muratozturk@selcuk.edu.tr
}

\section{Introduction}

As a result of the earthquakes in the last 20 years in Turkey, improving the seismic behavior of the structures and improving their performance levels have been among the most important issues of earthquake engineering. It was revealed that the existing building stock, especially after Marmara earthquake in 1999, was inadequate earthquake resistance for earthquake effects. 50,000-100,000 buildings were heavily damaged and tens of thousands of people lost their lives in the Marmara earthquake $(M w=7.4)$ in 1999 [1]. After this earthquake, many strengthening projects have been designed and carried out. However, there are concerns about how these applications were carried out and how the performance of the strengthened structures would be during a possible earthquake. Therefore the experimental studies on strengthening play an important role in reflecting the behavior of the buildings under earthquake.

Field observations after earthquakes in developing countries reveal that formation of soft storey irregularity is one of the major reasons for the loss of life/damage in the buildings [2-5]. The most important reason for this is the use of especially the ground floors for commercial purposes. Infill walls on the ground floor are removed in order to make presentations, and also, the height of the ground floor is increased compared to the upper floors by constructing mezzanine floors. These two factors considerably reduce the rigidity of ground floors. The infill walls, which are considered to affect the structure only as a vertical load during the design stage (non-bearing elements), both contribute to the bearing of lateral loads and limit story drifts by applying reactions to the column-beam joint areas. Therefore, the increase of the story height in addition to the removal of the infill walls leads to a sudden decrease in the rigidity of the ground floor. Since the shear walls, which provide the structure with lateral rigidity, are usually very limited in the existing building structure, the damage concentrates on the ground floor. Since they do not comply with earthquake code requirements, the columns with limited deformation capacity are fractured without consuming sufficient energy and the building usually collapse on the ground floor after the plastic hinges formed on the column ends. 


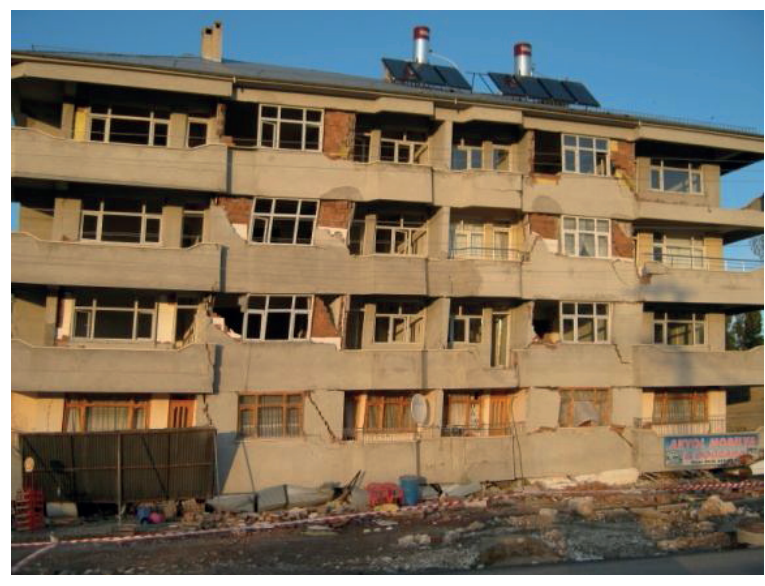

(a)

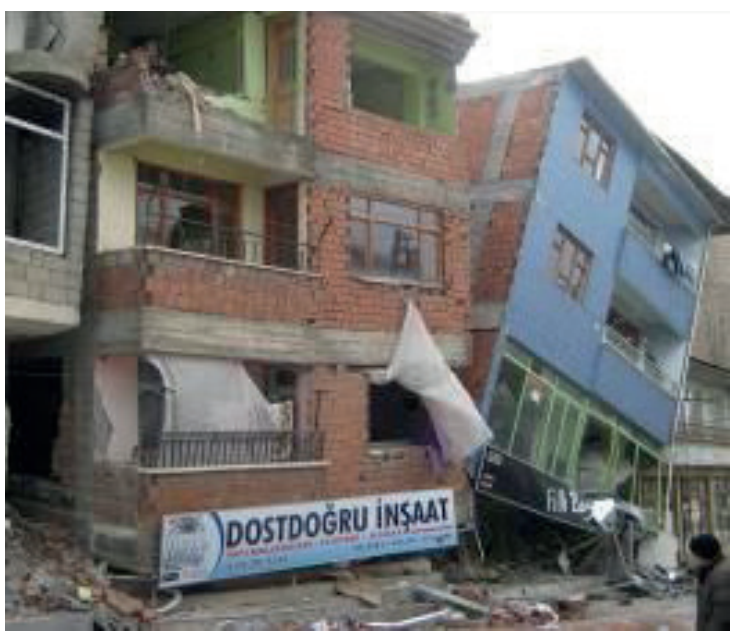

(b)

Fig. 1 Collapsed ground stories in 2011 Van, Turkey earthquake (soft storey mechanism) [3]

The analytical and experimental studies show that infill walls increase lateral load-carrying capacity and initial rigidity by up to $50 \%$ [5-8]. According to the Turkish Earthquake Code2007 (TEC -2007) [9] soft storey formation defined as; the ratio of the average storey drift at any storey to the average storey drift at the storey immediately above or below, is greater than 2. Figure 1 shows some structures in the Erciş district that observed soft storey damage during October 23, 2011, Van, Turkey earthquake.

In this study, the frames with soft storey irregularity, which are very common in developing countries, are strengthened by using steel profiles instead of the infill walls that have been removed for commercial purposes. 4 identical frames with 2 stories and single span were constructed. The first frame (Exp1-F) is the reference frame with brick infill walls on both stories, and the second frame (Exp2-SS) is the one with soft storey behavior on which the infill wall on the lower floor is removed. The first frame of the remaining two was strengthened by using steel profiles in reverse $\mathrm{V}$ shape on the ground floor by considering the human traffic (Exp3-SV). The 4th specimen was strengthened by using steel profiles of the same size in X shape (Exp4-SX).

\section{Experimental work}

\subsection{Description of test specimens, material properties and testing procedure}

The bare reinforced concrete (RC) frame was designed in accordance with the dimensions of the columns and beams in existing buildings and the span-height conditions and was prepared in 1/3 geometric scale. The out-to-out distance on the span in the RC frame is $1500 \mathrm{~mm}$ and the height of the floor is $1200 \mathrm{~mm}$ from the foundation to the upper level of the beam of the 1 st floor. The height of the 2 nd floor is $900 \mathrm{~mm}$. Thus, the height of the ground floor was increased and lateral rigidity of the lower floor was reduced as frequently seen at the buildings used for commercial purposes. Since the rotation and settlement on the foundation would not be considered in the study, the dimensions of the foundation were selected to be quite rigid and a foundation beam with the dimensions of $500 \times 700 \times 2500$ $\mathrm{mm}$ was produced. The column dimensions were decided to be $100 \times 150 \mathrm{~mm}$. Beam dimensions were also decided to be 150 $\times 150 \mathrm{~mm}$ in order to ensure strong beam-weak column formation which is a construction defect observed frequently in the existing building stock. The longitudinal reinforcement of the columns was prepared in $4 \varnothing 10 \mathrm{~mm}$ and produced by using stirrup with $\varnothing 4 / 100 \mathrm{~mm}$. No confinement zones were formed at the ends of the columns; the stirrups were not extended at the foundation and beam-column joints. Longitudinal reinforcements of $3 \varnothing 10 \mathrm{~mm}$ at the top, and $3 \varnothing 10 \mathrm{~mm}$ at the bottom and transverse reinforcement of $\varnothing 4 / 100 \mathrm{~mm}$ were applied to the beams. As can be understood from the design of the frames, many design defects in the existing building stock in the developing countries were considered.

In the field surveys carried out after devastating earthquakes in Turkey, it was observed that the average concrete compressive strength in existing structures ranged between 10-15 MPa. Therefore, the concrete compressive strength in the experimental study was chosen to remain within this range, and the concrete strength of the specimens taken during concrete casting was determined to be $13 \mathrm{MPa}$.

Brick infill wall with the width of $85 \mathrm{~mm}$ was built on both floors at specimen 1 (Exp1-F) which was considered as reference specimen. Then brick walls plastered with sand, cement, lime and water mortar. Plaster was applied to both sides of the wall. The thickness of the plaster that was used at two faces of brick walls was $7 \mathrm{~mm}$. Finally, the plaster surfaces painted with white paint to better see the cracks. The compressive strength of bricks was measured as $12 \mathrm{MPa}$ parallel to the gaps, 2.8 $\mathrm{MPa}$ perpendicular to the gaps in short direction and $3.2 \mathrm{MPa}$ perpendicular to the gaps in long direction. The frame with soft storey irregularity (Exp2-SS) has the same dimensions and reinforcement details as the reference frame. Its difference from the reference specimen is that there is no brick wall in the $\mathrm{RC}$ frame on the lower floor. Thus, the changes in the behavior of the frame were observed by formation of soft storey 


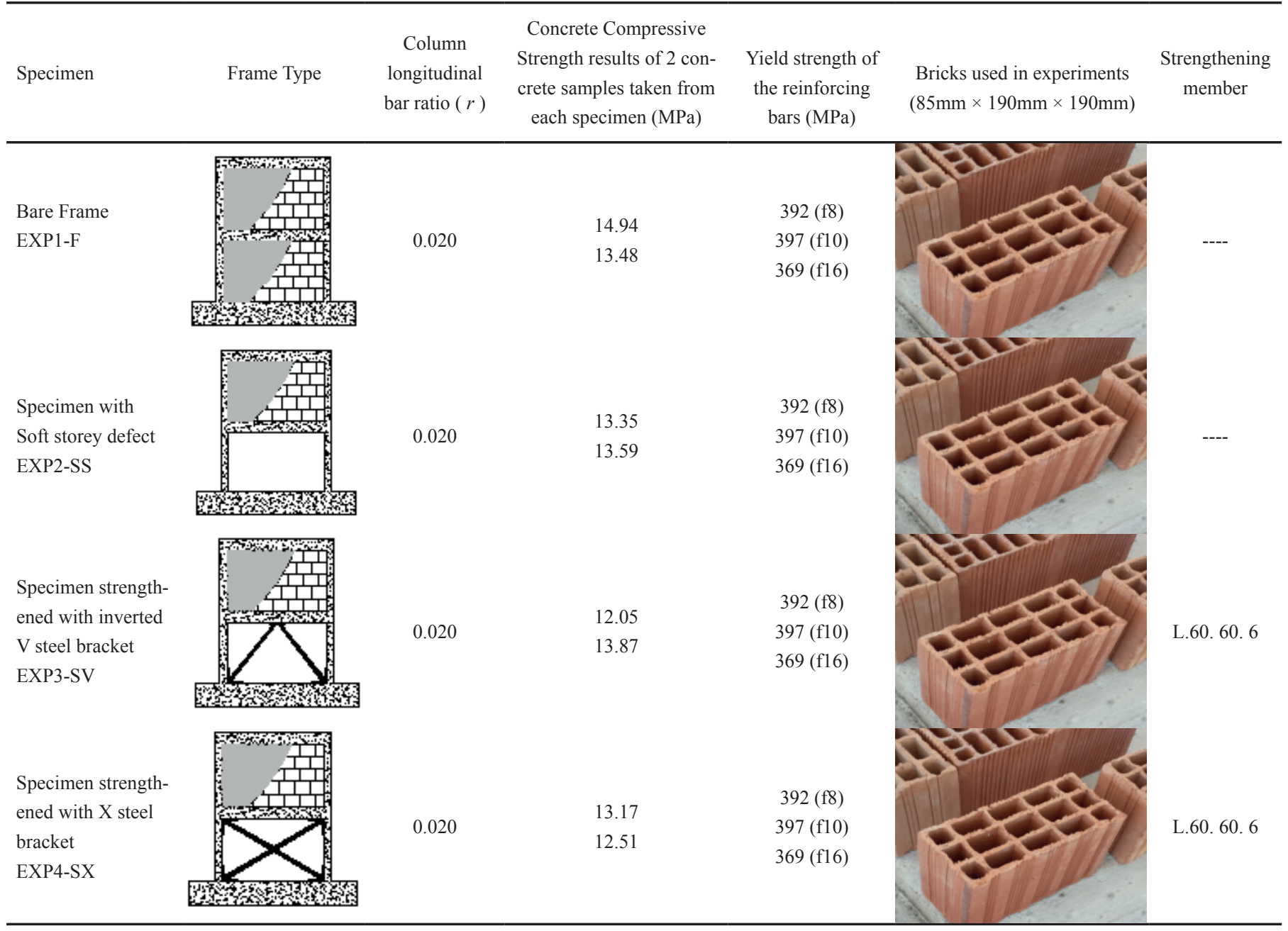

irregularity. Instead of the infill walls removed from the lower floors in the remaining 2 specimens, ST37-type steel profile with cross-sectional dimensions of L60.60.6 $\mathrm{mm}$ was used to make central $\mathrm{X}$ and inverted $\mathrm{V}$-shaped strengthening. The steel profiles were connected to the frame by using M16 anchorage bolts. No chemical adhesive was used during the anchorage. Since the ends of the bolts are hold with the concrete after they were inserted into the drilled holes, they were mechanically connected. General characteristics of the test specimens are showed at the Table 1, reinforcement and connection details of the specimens are showed at the Figure 2.a-c. A schematic illustration of test set-up and loading system is shown in Figure 2.b-2.d for specimen Exp2-SS. The horizontal load applied to the frame to represent the earthquake effect is applied from the upper peak point in some studies [10]. But to ensure accurate representation of the actual distribution of earthquake force on the structure, lateral loads should be applied on story levels at various rates (triangular load distribution) [11]. To this end, a special loading system was designed in this study. Load cell was fixed to a steel plate and by means of making a vertical box profile system with a hinge to the end of this steel sheet; it is aimed to move easily the system at the different displacements that may occur between the floors of RC frames.

\section{Experimental results}

\subsection{General behaviour of test specimens}

The displacement history graphs and load-displacement envelope curves that were observed during testing are illustrated in Figure 3. Also load history graphs are illustrated in Figure 4. Response envelope curves shown in Figure 3 were plotted by connecting the peak points of lateral load-top displacement hysteretic curves for each specimen. Response envelope curves show the strength and rigidity characteristics of the specimens and also their general behavior. Also, the view of the test specimens at the failure stage and the schematic representation of the cracks observed during testing are illustrated in Figure 5. While the maximum load obtained from EXP1-F specimen was approximately $62.86 \mathrm{kN}$ for positive loading, it was $22.11 \mathrm{kN}$ at the end of the $22 \mathrm{nd}$ cycle. And, the maximum load, which was $-67.67 \mathrm{kN}$, for the negative loading was reduced to $-24.78 \mathrm{kN}$. Therefore, the load bearing capacity was reduced by $60 \%$ at the end of the test. As can be seen from the displacement history graph given in Figure 3, Exp1-F specimen reached an ultimate peak displacement of 60 $\mathrm{mm}$. As shown in the damage drawings in Figure 5, there were specific $X$ cracks on the infill walls. And also, the crushing on the infill walls caused short column effect in the further loops. 

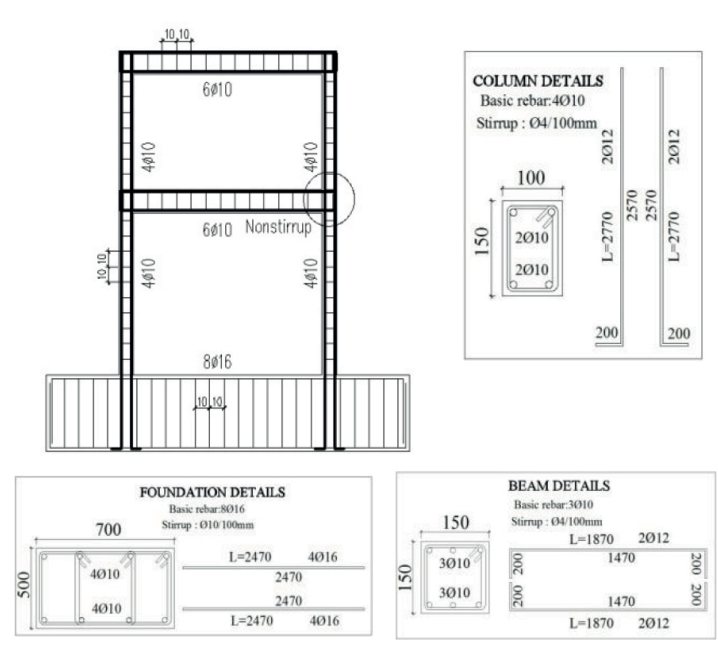

(a)

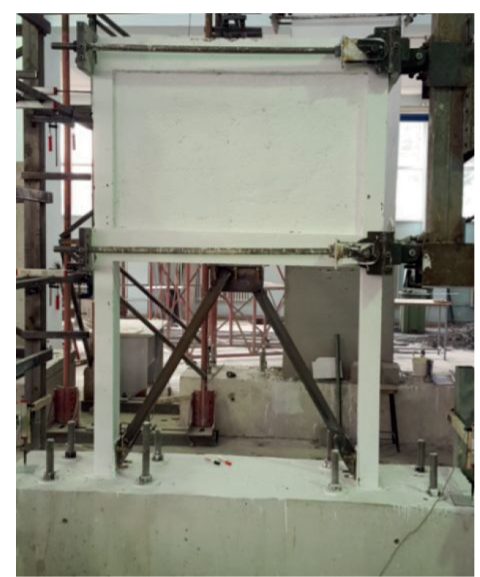

(c)

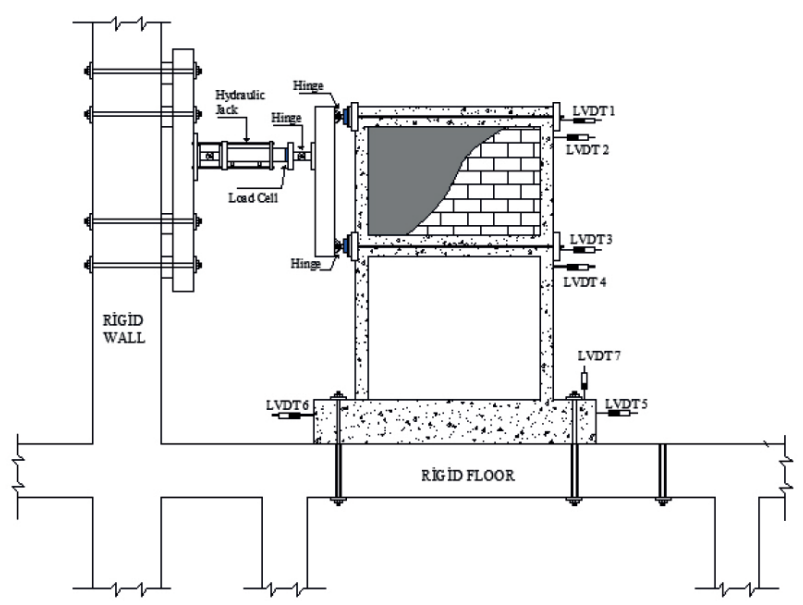

(b)

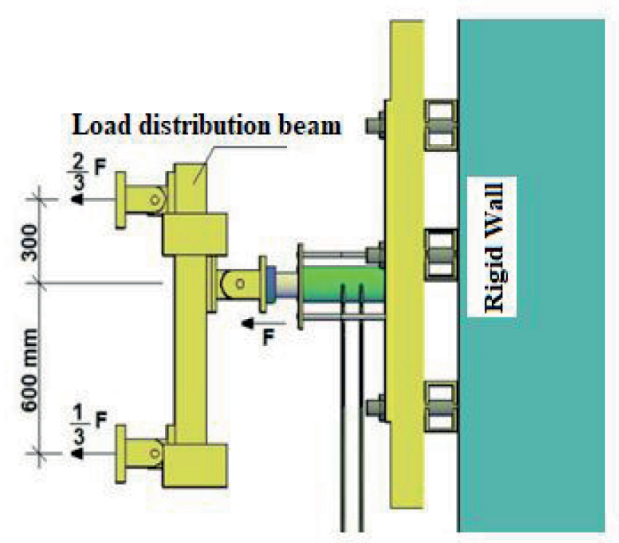

(d)

Fig. 2 (a) Reinforcement details of the frames (b) Loading system, test set-up for Exp2-SS specimen (c) view of EXP3-SV specimen (d) load distribution

While the maximum load value at Exp2-SS specimen was approximately $22.00 \mathrm{kN}$ for positive loading, it was $17.00 \mathrm{kN}$ at the end of the 14th cycle. And, the maximum load, which was $-22.00 \mathrm{kN}$, for the negative loading was reduced to -17.40 $\mathrm{kN}$. The maximum peak displacement was measured as $70 \mathrm{~mm}$. Cracks and damages were completely concentrated on the lower floor due to the effect of soft storey formation. The specimen reached the capacity by the formation of plastic hinges at the ends of the lower columns whose deformation capacity were limited. The maximum lateral load was measured as $80.00 \mathrm{kN}$ on the specimen Exp3-SV, which was strengthened by using diagonal steel elements in inverted V-shape on the ground floor. And the peak displacement value under this load was determined to be $27.80 \mathrm{~mm}$. The maximum displacement value in the specimen was determined to be $60.00 \mathrm{~mm}$ and the lateral load at this displacement value was determined as $43.00 \mathrm{kN}$. Therefore, the load carrying capacity was reduced by $45 \%$ at the end of the test. When the displacement value got $60 \mathrm{~mm}$ on the specimen, the buckling of the steel profiles was observed. The total load at this displacement value was determined as $43.00 \mathrm{kN}$. It is observed that vertical cracks were occurred at the connection region in beam where the $\mathrm{V}$ cross was connected, based on peel at the anchors. (Figure 5.b. crack no: 35-39).
The maximum lateral load was measured as $-64.00 \mathrm{kN}$ on the specimen Exp4-SX, which was strengthened by using diagonal steel elements in X shape. And the peak displacement value under this load was determined to be $-15.53 \mathrm{~mm}$. The maximum displacement value in the specimen was determined to be $-55.00 \mathrm{~mm}$ and the lateral load at this displacement value was determined as $58.00 \mathrm{kN}$. Therefore, loading was stopped after the load bearing capacity was reduced by $15 \%$. It was observed that, this specimen shows similar behaviors like EXP1-F, but sliding cracking was occurred much more obviously.

\subsection{Comparisons of strength and energy dissipation capacities of test specimens}

Comparisons of response envelope curves are shown in Figure 6.a. and comparisons of energy dissipation characteristics for specimens are shown in Figure 6.b. When we consider test results; soft storey frame's (EXP2-SS) strength was decreased $\% 65$ in positive cycles, and \%68 in negative cycles in comparison with reference specimen (EXP1-F). EXP4-SX specimen was reached to $\% 2$ more maximum load in positive cycles, and $\% 5$ less maximum load in negative cycles in comparison with reference specimen (EXP1-F). So EXP4-SX and EXP1-F 

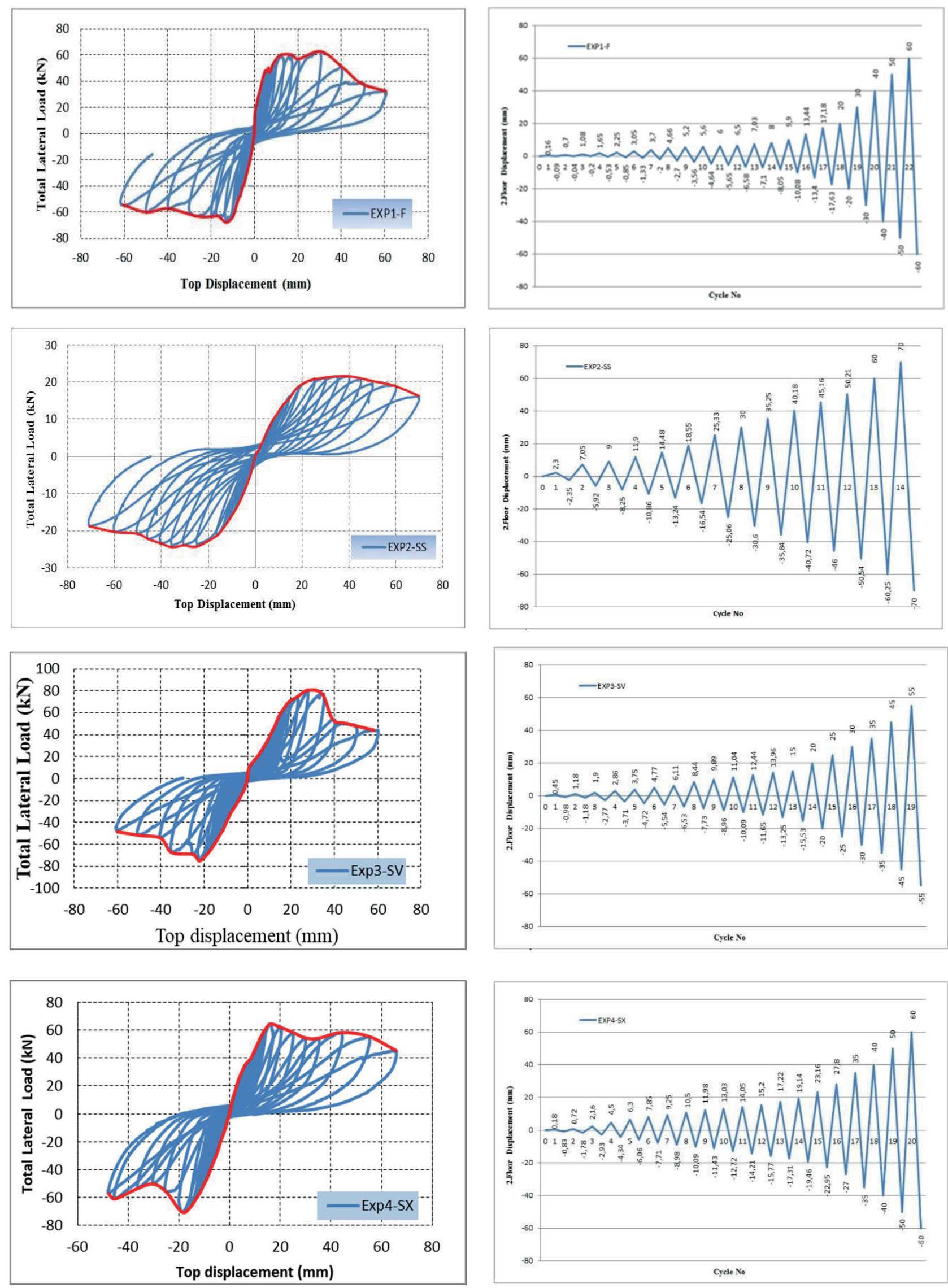

(a)

(b)

Fig. 3 (a) hysteresis and envelope curves of test specimens [12] (b) 2nd floor displacement-cyclic graphics of test specimens 

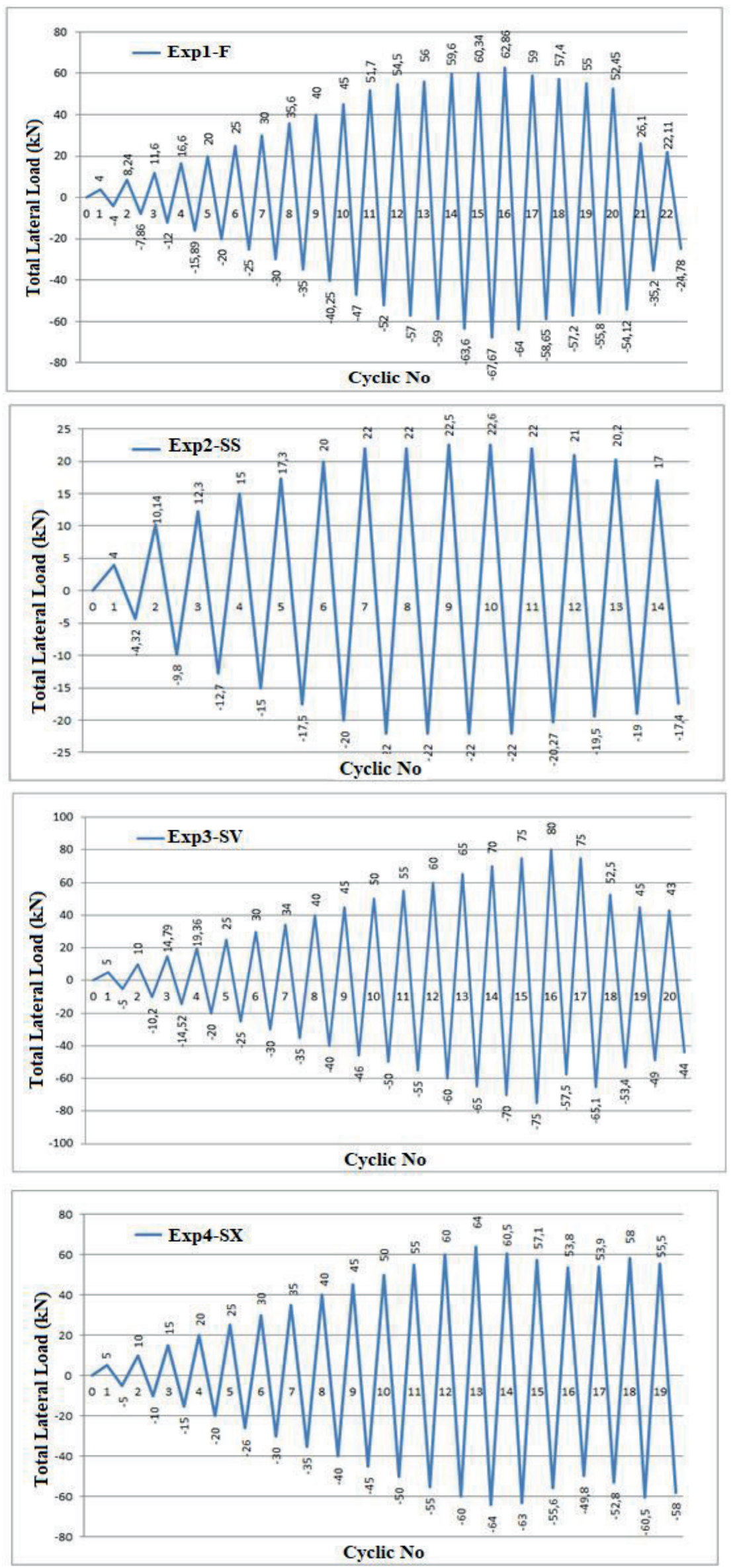

Fig. 4 Total Lateral Load - cyclic graphics of test specimens [12] 

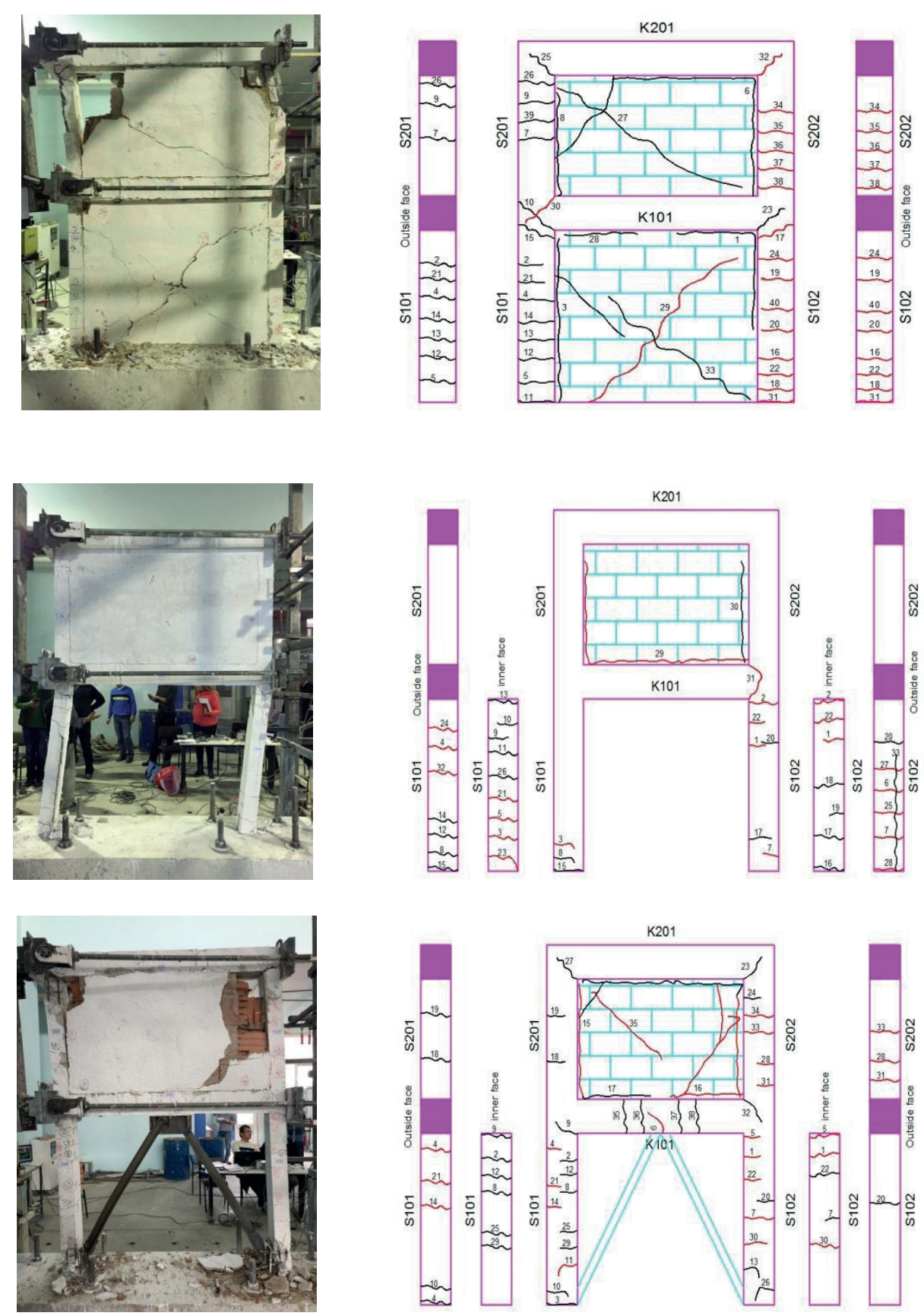

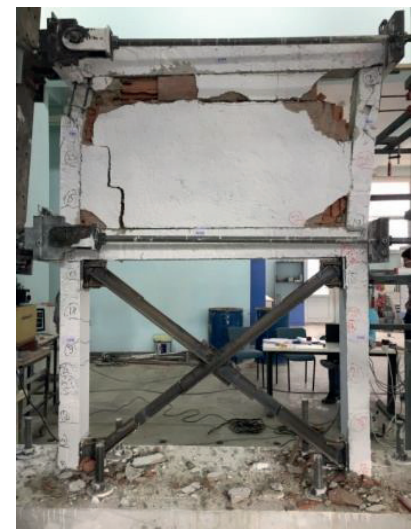

(a)

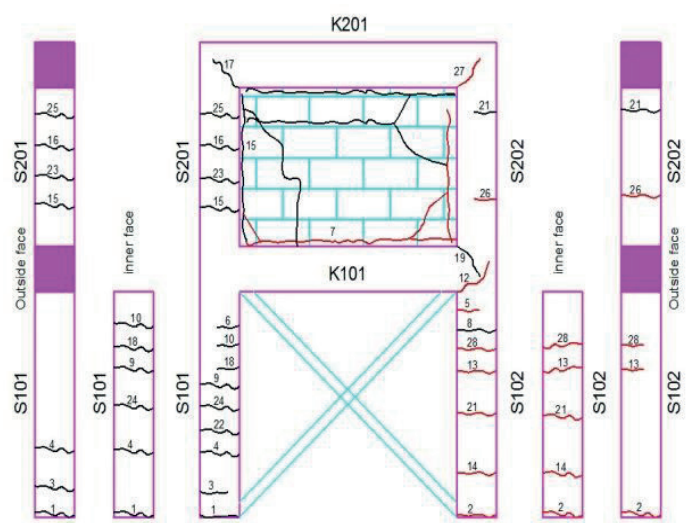

(b)

Fig. 5 (a) The view of the test specimens at the end of the tests (b) schematic representation of the cracks observed during testing [12] 


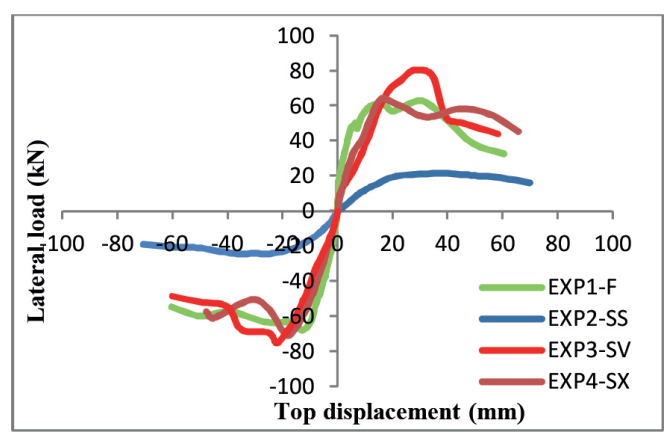

(a)

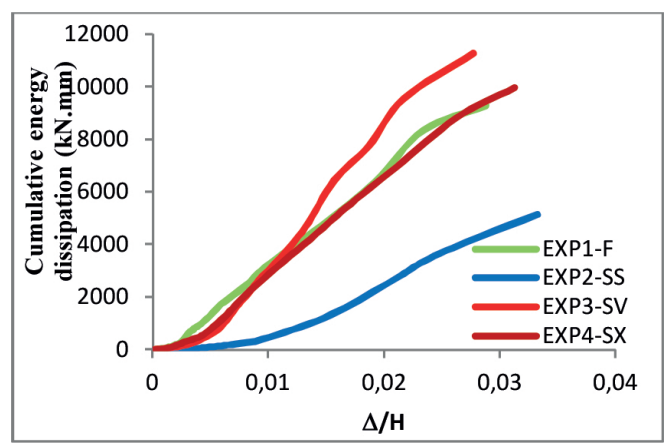

(b)

Fig. 6 (a) Comparison of lateral load-top displacement envelope curves (b) Comparison of energy dissipation characteristics of specimens

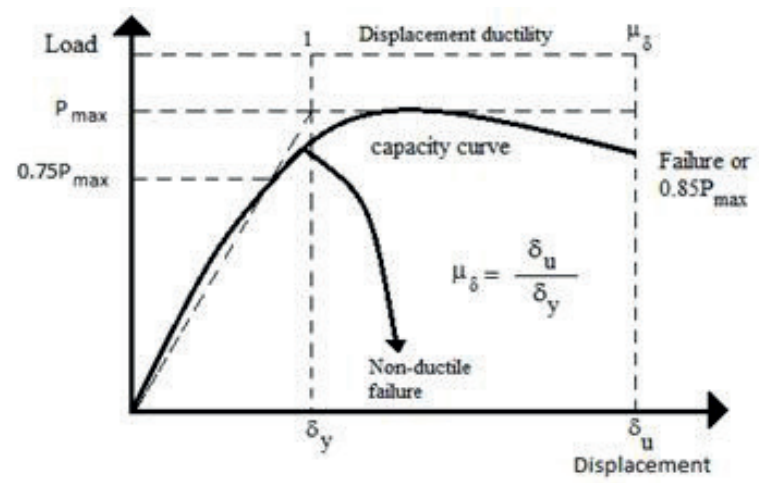

Fig. 7 A typical load-displacement relationship and definition of the displacementductility for reinforced concrete structural elements [15]

specimens showed nearly the same behaviour in terms of lateral load capacity. Exp3-SV test specimens were reached to \% 27 more maximum load in positive cycle, and \% 11 more maximum loads in negative cycle in comparison with reference specimen (EXP1-F). As can be seen from the energy graphics which are given at Figure 6.b., EXP2-SS specimen was consumed $\% 54$ less energy than EXP1-F specimen at the last cycle. So soft storey formation was highly reduced energy dissipation capacity of frame. EXP3-SV, EXP4-SX specimens were consumed $\% 22$ and \%8 more energy than EXP1-F specimen at the end of the test, respectively. Dissipated energy values were obtained by detecting the areas limited by load-displacement loop in each cycle with the help of test result data. For this purpose, the area under the load-displacement curve in the forward cycle was first calculated. Later the area under the load-displacement curve in the backward cycle is calculated and the total energy consumed for this cycle is calculated by summing these values. Then by consecutively summing these areas the total energy dissipation was calculated. Accordingly, values at the collapse point refer to the energy dissipated by specimens.

Test results are summarized in Table 2. Table 2 presents load and displacement values of the test specimens in yield, maximum load and collapse modes and upper storey displacement rates and displacement ductility coefficients in these modes. Yield displacement is obtained by idealizing total load-top displacement envelope curve according to the two-line elasto-plastic behaviour model. Linear and nonlinear capacity curves overlap at the point which corresponds to $75 \%$ of the load-bearing capacity of the system $[14,15]$. The literature states that the value recorded at the moment when capacity reduction reaches $15 \%$ or $20 \%$ can be taken as the collapse displacement value [11,16-17]. In the present study, $15 \%$ capacity reduction was taken as the basis for the collapse displacement. A typical load-displacement relationship obtained in the scope of these definitions is given in Figure 7 [15].

\section{Conclusions}

The soft storey formation, which is frequently observed in the existing building stock in developing countries, is one of the most important causes of building damages during the earthquakes.

In this study, the effect of brick infill walls on reinforced concrete frames with soft storey irregularity was examined and the behavioral changes caused by strengthening the frames using diagonal steel elements in central $\mathrm{X}$ and inverted $\mathrm{V}$ type instead of infill walls on the ground floor were also investigated. Four RC frames with $1 / 3$ geometrical scale with two stories and a single span were tested under reverse cyclic loading simulating the earthquake.

While the frame with soft storey irregularity reached $22 \mathrm{kN}$ lateral load carrying capacity, the infill wall addition (reference frame) increased the capacity by 3 times. Therefore, it is observed that the infill walls, which are generally considered by only their weights in construction analysis, contribute to the system's lateral load-carrying capacity and rigidity significantly. Therefore, the infill wall effect should be defined in the regulations. The frames which were strengthened by using diagonal steel elements reached between $2 \%$ and $20 \%$ more lateral load carrying capacity than the reference frame. When the strengthened specimens are compared to each other, the specimen strengthened with diagonal inverted V steel profile carried $25 \%$ more load in the forward loading than the specimen with diagonal steel element with $\mathrm{X}$ shape. Considering both the increase in load-carrying capacity and the use for architectural factors, it may be more realistic to prefer inverted V-type strengthening which seems more suitable for commercial buildings. When the energy dissipation of the tested specimens is examined, they are ranked as the frame with soft storey irregularity, the reference frame, the frame with X-type strengthening, and the 
Table 2 Lateral load and top displacement values of test specimens for different load levels

\begin{tabular}{|c|c|c|c|c|c|c|c|c|}
\hline \multirow{2}{*}{$\begin{array}{l}\text { Loading } \\
\text { Direction }\end{array}$} & \multirow[b]{2}{*}{ Specimen } & \multicolumn{2}{|c|}{ Yielding } & \multicolumn{2}{|c|}{ Maximum Lateral Load } & \multicolumn{2}{|c|}{ Failure } & \multirow{2}{*}{$\begin{array}{r}\text { Displacement } \\
\text { ductility ratio, } \mu\end{array}$} \\
\hline & & $0.75 \operatorname{Pmax}(\mathrm{kN})$ & $\begin{array}{l}\text { Top displa. } \\
(\mathrm{mm}), \delta \mathrm{y}\end{array}$ & Load $(\mathrm{kN})$ & $\begin{array}{l}\text { Top displa. } \\
\text { (mm) }\end{array}$ & Load $(\mathrm{kN})$ & $\begin{array}{l}\text { Top displa. } \\
(\mathrm{mm}), \delta \mathrm{u}\end{array}$ & \\
\hline \multirow{4}{*}{$\begin{array}{l}\text { Forward } \\
\text { cycle }\end{array}$} & EXP1-F & 47.15 & 6.20 & 62.87 & 12.37 & 53.44 & 38.37 & 6.19 \\
\hline & EXP2-SS & 16.17 & 20.37 & 21.53 & 34.88 & 18.30 & 62.10 & 3.04 \\
\hline & EXP3-SV & 60.24 & 16.48 & 80.33 & 27.68 & 68.28 & 36.25 & 2.20 \\
\hline & EXP4-SX & 48.28 & 14.17 & 64.38 & 16.20 & 54.73 & 55.75 & 3.93 \\
\hline \multirow{4}{*}{$\begin{array}{l}\text { Backward } \\
\text { cycle }\end{array}$} & EXP1-F & 50.75 & 10.02 & 67.67 & 13.10 & 57.52 & 38.58 & 3.85 \\
\hline & EXP2-SS & 18.36 & 16.70 & 24.48 & 35.34 & 20.81 & 52.39 & 3.14 \\
\hline & EXP3-SV & 56.34 & 16.97 & 75.13 & 22.32 & 63.86 & 36.47 & 2.15 \\
\hline & EXP4-SX & 52.76 & 14.19 & 70.35 & 18.84 & 59.79 & 44.73 & 3.15 \\
\hline
\end{tabular}

one with V-type strengthening. Therefore, the strengthening by using steel diagonals in inverted-V shape seems to get the best result. Since the frame with $\mathrm{X}$ diagonal is connected to the weak beam-column connection area with no stirrups, relatively low energy consumption and load-carrying capacity were achieved. Also, the anchors made by mechanical clamping performed their tasks, thus the load carrying capacity of the strengthened frames reached to the reference frame strength.

As a result; if soft storey formation on the ground floors cannot be avoided especially for the buildings used for commercial purposes, strengthening by using steel elements is a good method to protect the building during the earthquake by increasing the lateral load-bearing capacity, rigidity, and energy dissipation of the system.

\section{Acknowledgement}

The authors thank Selcuk University, Scientific Research Project Funding (SU-BAP) for their financial support [Project number: 15201088$]$

\section{References}

[1] Sezen, H., Whittaker, A. S., Elwood, K. J., Mosalam, K. M. "Performance of reinforced concrete buildings during the August 17, 1999 Kocaeli, Turkey earthquake, and seismic design and construction practice in Turkey". Engineering Structures, 25(1), pp. 103-14. 2003. https://doi.org/10.1016/S0141-0296(02)00121-9

[2] Dogangun, A. "Performance of reinforced concrete buildings during the May 1, 2003 Bingöl earthquake in Turkey". Engineering Structures, 26(6), pp. 841-856. 2004.

https://doi.org/10.1016/j.engstruct.2004.02.005

[3] Ozturk, M. "Field Reconnaissance of the October 23, 2011, Van, Turkey, Earthquake: Lessons from Structural Damages". Journal of Performance of Constructed Facilities, 29(5), 2015.

https://doi.org/10.1061/(ASCE)CF.1943-5509.0000532

[4] Inel, M., Ozmen, H. B., Bilgin, H. "Re-evaluation of building damage during recent earthquakes in Turkey". Engineering Structures, 30(2), pp. 412-427. 2008.

https://doi.org/10.1016/j.engstruct.2007.04.012

[5] Climent, A. B., Paez, S. M. "Earthquake retrofitting of R/C frames with soft first story using hysteretic dampers: Energy-based design method and evaluation". Engineering Structures, 137, 19-32. 2017.

https://doi.org/10.1016/j.engstruct.2017.01.053
[6] Arslan, M. H., Korkmaz, H. H. "What is to be learned from damage and failure of reinforced concrete structures during recent earthquakes in Turkey". Engineering Failure Analysis, 14(1), pp. 1-22. 2007.

https://doi.org/10.1016/j.engfailanal.2006.01.003

[7] Demirel, I. O., Yakut, A., Binici, B., Canbay, E. "An Experimental Investigation of Infill Behaviour in RC Frames". In: Proceedings of the Tenth Pacific Conference on Earthquake Engineering Building an EarthquakeResilient Pacific, 6-8. November, Sydney, Australia, 2015.

[8] Yakut, A., Binici, B., Demirel, I. O., Özcebe, G. "Effect of Infill Walls on Earthquake Response". In: Second Turkey Conference on Earthquake Engineering and Seismology, 25-27. September, Hatay, Turkey, 2013.

[9] Turkish Earthquake Code (TEC-07). Specification for Buildings to be Built in Seismic Zones, Ministry of Public Works and Settlement Government of Republic of Turkey, Ankara, 2007.

[10] Haris, I., Hortobágyi, Zs. "Comparison of experimental and analytical results on masonry infilled RC frames for monotonic increasing lateral load". Periodica Polytechnica Civil Engineering , 56(2), pp. 185-196. 2012. https://doi.org/10.3311/pp.ci.2012-2.05

[11] Altin, S., Anil, O., Kara, M. E. "Strengthening of RC nonductile frames with RC infills: An experimental study". Cement and Concrete Composites, 30(7), 612-621. 2008.

https://doi.org/10.1016/j.cemconcomp.2007.07.003

[12] Ogutcu, T. F. "An Experimental Investigation On Soft Story Formation At The Nonductile RC Frames". MSc Thesis, Selcuk University, Konya, Turkey [in Turkish], 2016.

[13] Balık, FS. "Window Opening Effects In Strengthening Of Rc Frames With Inadequate Eq Performance By Using Rc Shear Wall". Phd Thesis, Selcuk University, Konya, Turkey [in Turkish], 2012

[14] Lu, Y., Hao, H., Carydis, P. G., Mouzakis, H. "Seismic performance of RC frames designed for three different ductility levels", Engineering Structures, 23(5), pp. 537-547, 2001. https://doi.org/10.1016/S0141-0296(00)00058-4

[15] Yuksel, I., Polat, Z. "Yield state investigation of reinforced concrete frames from a new point of view". Engineering Structures, 27(1), pp. 119-127, 2005.

https://doi.org/10.1016/j.engstruct.2004.09.006

[16] Kazemi, MT., Morshed, R. "Seismic shear strengthening of RC columns with ferrocement jacket", Cement and Concrete Composites, 27(7-8), pp. 834-842, 2005.

https://doi.org/10.1016/j.cemconcomp.2005.03.011

[17] Kaltakci, M. Y., Ozturk, M. "An experimental study on the strengthening of non-ductile reinforced concrete frames via external shear wall". European Journal of Environmental and Civil Engineering, 16(1), pp. 59-76, 2012.

https://doi.org/10.1080/19648189.2012.667672 